\title{
MONITORING OF CZECH LANDSCAPE DEVELOPMENT USING GIS AND REMOTE SENSING
}

J. Kolejka, J . Ž a lou dík: Monitoring of Czech Landscape Development Using GIS and Remote Sensing. - Geografie-Sborník CGS, 111, 1, pp. 70-91 (2006). - Historical studies of landscape represent a part of traditional research in Czech geography. Modern technologies allow carrying out more accurate, more detail and more extended research actions. Methodically the historical landscape studies are supported with rich territorial databases of maps and aerial/satellite imagery. Examples presented in the paper document typical ways of GIS and RS applications starting with digital multitemporal imagery analysis to the utilizing of digital landscape model as fully integrated and sophisticated database supporting landscape analysis with respect to both natural and social area features.

KEY WORDS: landscape history - digital monitoring techniques - GIS and remote sensing - digital landscape model.

\section{Introduction}

Landscape is a multi-dimensional geographical object. One of its dimensions harmoniously blending with the other landscape qualities is time. In terms of forming landscape, man represents a significant factor. The role of man in Czech landscape has undergone dramatic changes related to the area, character and intensity of such an impact. The contemporary landscape is always a product of a co-operation of natural and anthropogenous factors working in a wide range of mutual interactions. The final outcome is a colourful mosaic of individual forms of landscape cover and manifold types of cultural landscape covering the Czech Republic.

Historical changes in land use have always been a popular subject of geographical and landscape-ecological research. However, geoinformation technologies have enabled people to carry out the research multilaterally, efficiently, to integrate a number of differing data and to do it practically upon request. Moreover, if we have an intimate knowledge of the given area's natural features we can reveal whether the changes' motive can also be constituted by the site's .different qualities. From a time series of changes we can then deduce the types of land use changes a given type of environment has undergone. Analogically, we can expect a similar development in other areas, which is interesting for landscape planning. While remote sensing and the technologies of global positioning systems are alongside cartography important sources of data, the technologies of geographical information systems serve as a tool for their pre-processing, saving, thematic evaluation and, most importantly, for acquiring new information on the area. 


\section{Sources of the dynamics and development of Czech landscape}

Czech cultural landscape has been undergoing changes which reflect the economic and social events while respecting the area's natural determinants. It is a generally known fact that the landscape character is influenced by a wide range of factors. Among the natural agents are the global and local climates, macro- and meso-relief (position within the general layout of the area's relief and the position on the specific relief shape, including its gradient, exposure and altitude), the geological background, soil (the presence of fertile or barren soils), humidity conditions (proximity of a water plane, lack or surplus of humidity), local sources of free or fixed energy (wind, running water, biomass or fossil fuels, dramatic soil movements, including avalanches), biota character (autochtonous plant communities, present species of beneficial or invasive plants and animals) and others.

Among other things, economic conditions are determined by the area's position in relation to the local, regional or higher authorities, the current market situation (upturn or decline), prices of land, available workforce (its numbers, qualifications, work morale), raw materials and natural resources availability, relation to technical or communication infrastructure, the division of land into lots, taxation and others.

Socio-political factors are asserted through cultural and ideological influences, such as the impact of national and local traditions, population density and organization, people's education and religion, wealth, mentality, direct and indirect influence of the state and its authorities, people's standard of living and their leisure time, lifestyle, family character and others.

Indisputably, all these factors play a role in the development of cultural landscape. Yet, the ratio of their mutual interaction can vary from site to site. In most cases natural conditions have dominant impact, predominantly the climate and relief as natural parameters which cannot be influenced by people. Therefore it is the economic and human factors which greatly vary in their effect and mutual combinations, and which can respect the influence of natural background in different ways. This plurality has lead to the great diversity of world's, Europe's and present Czech cultural landscapes.

Owing to long-term directing of landscape processes towards production and other purpose-oriented roles the landscape systems structure has adapted both in spatial and functional context. Undesirable supraliminal reactions of landscape systems can also occur (such as erosion resulting from eliminating erosion control structures of small-scale farming).

At present globalization and its outcomes confront us in different forms, have impact on the everyday life of ordinary people and are directly reflected in the cultural landscape development in Czechia.

With regard to the development of urbanized landscape, our concepts are based on the fast developing network of super- and hypermarkets mushrooming along the main access roads and their crossroads, warehouses and production halls in industrial parks and their vicinities, towns slicing off the originally agricultural landscape into colonies of family houses and mini housing estates. However, the real processes taking place in agricultural landscape are not so apparent. It is true that there is a growing number of areas abandoned by large-scale farming and some industrial and mining activities. Roads are constructed and modernized. Many country settlements are subject to building development, at least in places of positive economic impact. We have almost got used to critical opinions frequently expressed on 
the past and present changes of our landscape. Amateur conservationist movements often do not spare an opportunity to express their criticism and in many cases it is difficult to contradict them. There is no denying that landscapes all over the world are going through both deliberate and undesirable negative changes. One of the objectives of this study is to demonstrate the traditional methods and technologies used in Czechia in order to effectively document historical changes in land use and to evaluate them.

\section{Analogue geo-spatial data on land use in the past and at present}

In the course of the last four hundred years a number of cartographic works documenting the contemporary situation in land use have originated in the
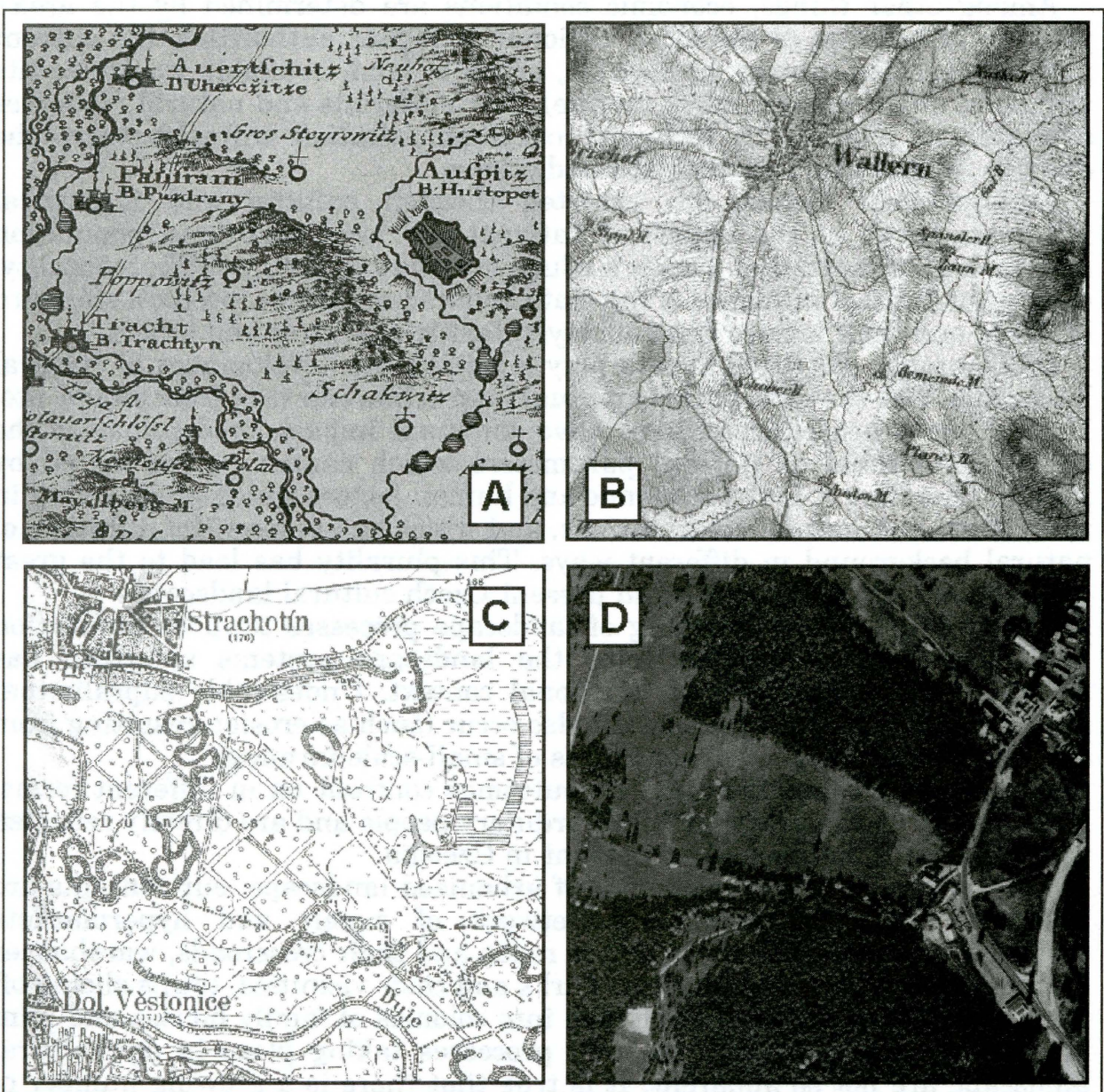

Fig.1 - Oldest detailed cover map of land use in Czechia - Müller's map (A), Example of georeferenced map list from the Second Military Survey (B), Re-ambulated map with a detailed representation of land use in the $1920 \mathrm{~s}(\mathrm{C})$, Black and white orthophotomap processed in GIS (D) 
area covering today's Czechia. In contrast to the period following the end of Middle Ages, when maps of mostly small scales presented a very rough layout of main settlement, forests and water planes (objects), Baroque times introduced a relatively exact documentation of some estates or their parts, usually gardens or manors. Maps covering a state's whole area were not drawn until the 18th century. In 1720 Müller's map of Bohemia was printed in the approximate scale of $1: 132000$, well recording the layout of forests and fishponds (Fig. 1A). In the second half of the same century (1764-83) the socalled First Military (Joseph's) Mapping was carried out in a similar scale (approximately 1 : 144000 ). Very exact data of very good quality were acquired through the cadastral measurements of the so-called stabile cadastre in 1824-46 which yielded map documentation of land use in the scale of $1: 2880$. These data were then used to complete maps of the so-called Second Military (Franciscus') Mapping (1836-52) in the scale $1: 28800$ (Fig. 1B). In the 1870 s maps of the renewed cadastre were made in the scale of $1: 2880$. At the same time the so-called Third Military Mapping was carried out in the scale $1: 25000(1876-80)$. From these data special topographic maps in the scale of $1: 75000$ and general map of $1: 200000$ were derived.

Shortly after the independent Czechoslovakia was established in 1918, reambulation of topographic maps in the scale of $1: 25000$ was carried out together with complementing them with contour line hypsography (in place of shading - Fig. 1C). During World War II topographic measuring in system S-42 (Gauss-Krüger) was carried out. Starting with the 1950s, topographic maps in the scales of $1: 10000,1: 25000,1: 50000,1: 100000,1: 200000$ and $1: 500000$ were made in the co-ordinate system S-JTSK (Krrovák). They were created for public use (with certain limitations) while reliably recording the contemporary land use. At present these maps are subject to periodical renewal and systematic digitalizing (and vectorizing). Another source of cartographic information are similar maps in the S-42 system produced by the former Czechoslovak People's Army, later Czech Army (1 : 25000 $-1: 500000$ ). Starting with the 1930s topographic maps have been renewed and complemented with the help of aerial surveying, initially black and white and as of the 1970s coloured. Since the late 1960s photographic records of the territory coming from Soviet satellites (Soyuz, KFA, KATE) have been available. Majority of analogue map and image data from the past have been recently transformed into digital raster form, the reason being more efficient archiving, protection of blueprints and most importantly to make them more accessible to users.

\section{Digital geo-spatial data on land use in the past and at present}

All the sheets of Müller's and the so-called military mappings from the 18th and 19th centuries have been recently scanned and rectified and are now accessible to the public on the Internet (http://oldmaps.geolab.cz). Majority of historical aerial surveys archived in Czechia are also being digitalized. Maps of the stabile cadastre from the first half of the 19th century are gradually digitalized. Czech Office for Surveying, Mapping and Cadastre is also transforming its archives of topographic maps into digital form. General public has had access to the files of ZABAGED 1 and 2. The first one contains a vectorized content of topographic maps of the whole Czechia in the S-JTSK 
system in the scale of $1: 10000$, the second one presents only one colour raster layer or sectional black and white layers of the same map file. The Military Institute of Geography and Meteorology in Dobruška offers vectorized layers of topographic maps in the scales of $1: 25000$ (DMÚ 25) and 1 : 200000 (DMÚ 200). These maps were mostly made with the help of photogrammetry in the $1990 \mathrm{~s}$, in some cases their content is of a later date. In these maps one can track down some of the main categories of land use in a given time period.

In the category of satellite data we have scanner (mostly multi-spectral) data from the Landsat satellites (since the mid-1970s), SPOT (since the 1980s), Kosmos (since the early 1980s) and a number of other satellites, including the high-definition data from recent times (Ikonos, Quick Bird and others).

Standard orto-rectified digital aerial surveying data have been available since the end of the 20th century (Fig.1 D). Colour digital orto-photomaps of the entire territory of the Czech Republic have been available since 2004.

The output of digital historic database of land use in Czechia in the past is represented by cartograms depicting the structure of land use in individual cadastre areas of Czechia based on 19th and 20th century censi (Bičík, Kupková 2001). These data in different combinations have also been used by Czech scholars for history-geographic studies. These have been implementing the GIS technology since mid-1980s and as of the 1990s have been using predominantly the software produced by ESRI.

\section{Orientation of the land use studies}

The process of anthropogenic landscape development lacks the typical auto-regulatory processes inherent in nature where natural landscape structure becomes an integral product of interacting local, regional and global factors which respect the laws of evolution and stability.

The emergence of human society brought about new environmental evolution agents which observe some auto-regulatory trends only on certain conditions. Viewed from this perspective, human history appears to be a battle of one species with its environment (Dorst 1974). Considering the fact that through landscape "cultivation" people created their own environment suitable for living, working and relaxing, history of mankind becomes a longterm process of creating a man-made environment while requiring enormous labour, time, material, energy, financial, and intellectual costs.

As the distance between people and nature continued to grow, balance between the factors of "destruction" and "creation" had to be maintained with the help of further spending.

The degree of depth or comprehensiveness of a landscape change and its study can be classified with regard to the localization exactness of the identified change (Fig. 2):

1. Chronological localization - registered change is related to a given date or period.

2. Statistic localization - registered change is related to a standard territorial statistic unit.

3. Geometric localization - identified change is related to a point, line or area described by geographic, metric or other positional coordinates.

4. Geographic localization - each individual change, groups or classes of changes are related to an individual type of geographic environment. 


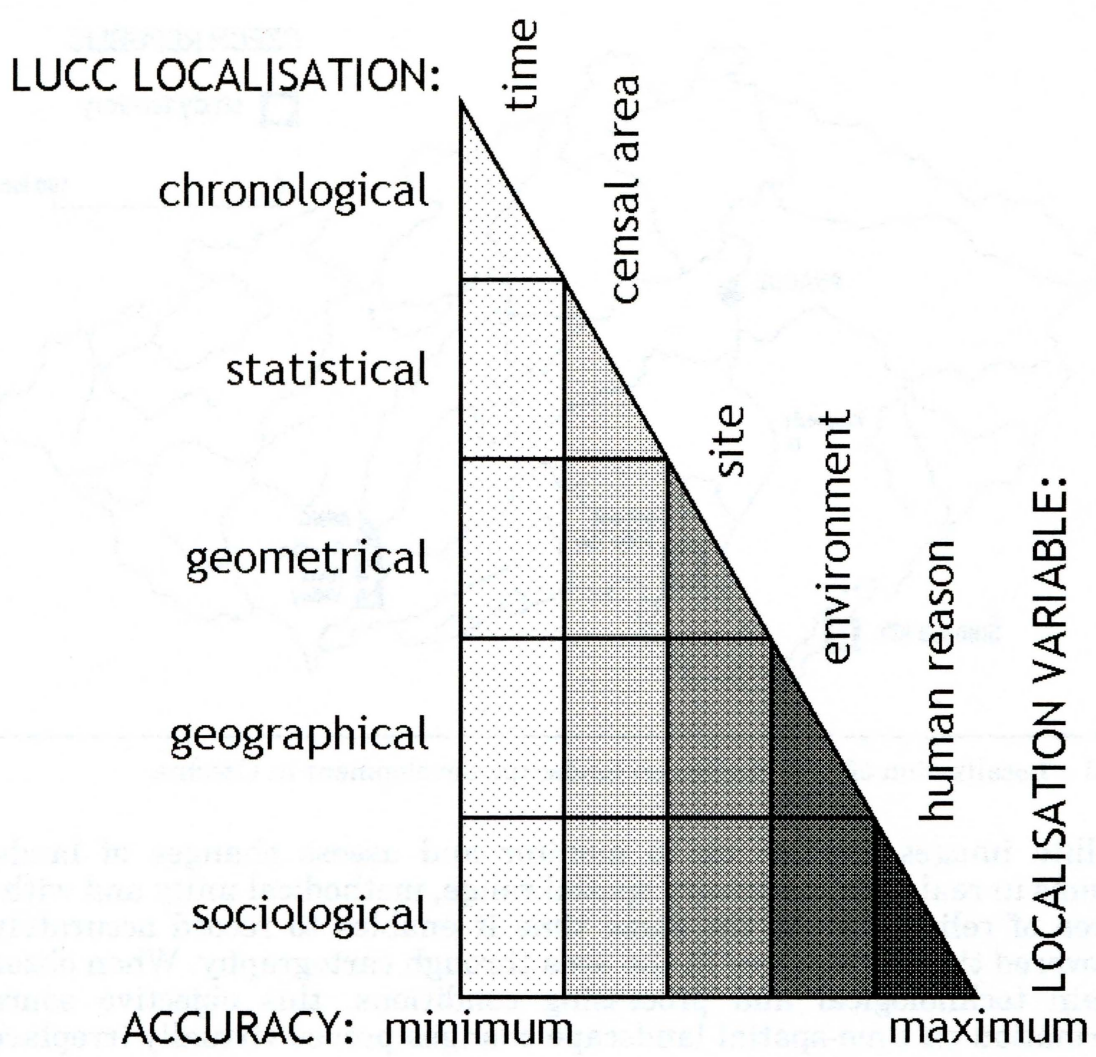

Fig. 2 - Relations between the comprehensiveness of land use and cover changes studies, the exactness of changes localization and the properties of a given change

5. Sociological localization - each individual change is localized and explained within the given social and economic context.

The most exact research brings the most reliable results and as such is the primary objective of many projects which must be completed in the shortest time possible. Such a research provides good answers to the questions of "What? When? Where and why?". If all these questions are properly answered, then development trends and regularities of landscape development are revealed. The knowledge of trends and development regularities are indispensable for forecasts of changes in landscape and its use. Selected results of studies on adequate exactness levels of landscape changes are listed below.

\section{Methodical samples of remote sensing data and GIS technology uses in landscape changes monitoring}

The methods of remote sensing are useful and effective precisely in the study of landscape objects and phenomena dynamics. The use of aerial and 


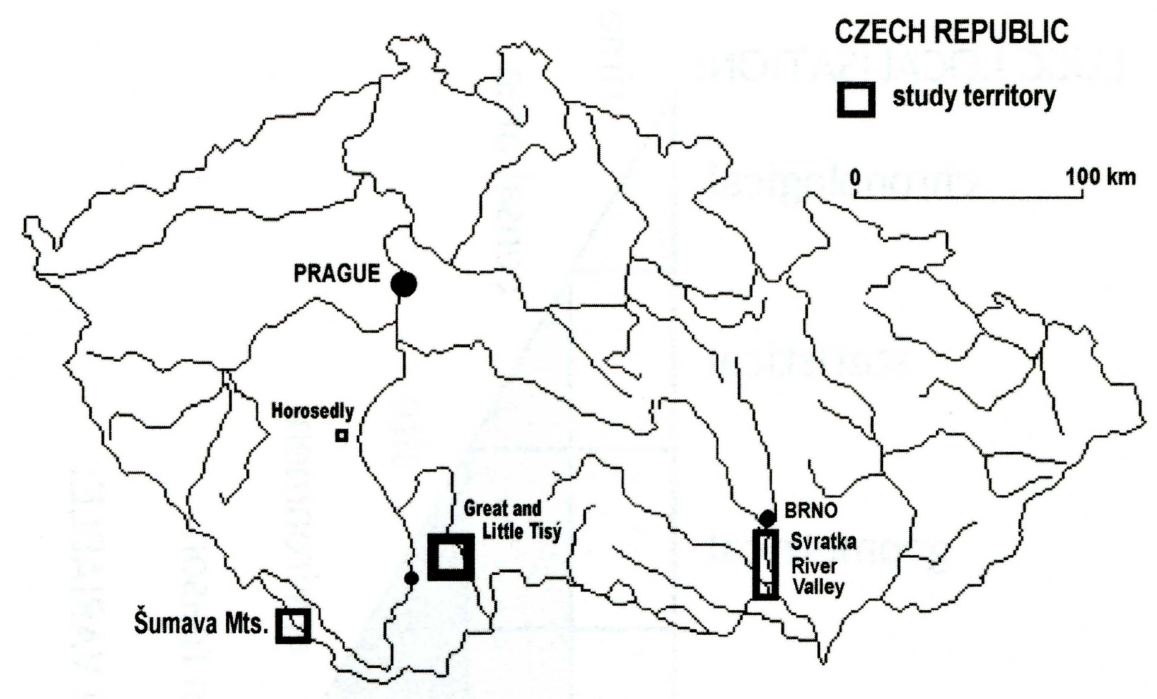

Fig. 3 - Localization of case studies on landscape development in Czechia

satellite images enables us to monitor and assess changes of landscape systems in real time, necessary spatial range, methodical unity and with high degree of reliability. At the same time it enables to record accurately the discovered time differences in the area through cartography. When observing certain technological and processing conditions, this objective source of information on time-spatial landscape changes proves virtually irreplaceable with terrestrial methods.

Large-scale aerial images are used predominantly for identification and exact localization of required object in landscape (usually through visual interpretation). However, they are equally useful in thematic categorization and quantification of spatial relations in the area. Recently they have been rivaled (in terms of technology, not prices) by satellite images of high and medium resolution. As for the implemented processing technologies, both simple optical-analogue methods of data interpretation (visual comparison and assessment of shapes, texture and location of the depicted objects) and digital methods of processing and assessment of remote sensing data (exact geometric corrections, creation of orthophotos, digitalization of objects' thematic layers and their quantitative analysis or modeling) find productive use in the work of landscape ecologists and geographers. The choice of used methods and data can be tailored to the desired purpose (needs and objectives of the project), financial limits and technical equipment of their users.

The contemporary modern technology of GIS has a virtually unlimited processing and presentation potential. It provides an expedient extension of remote sensing possibilities. The included methodical outline presenting structurally and functionally different model areas in Czechia (Fig. 3) demonstrates our experience with implementing remote sensing and GIS technologies in the detection and study of landscape changes. 
6. 1 Aerial imagery - monitoring and analysis of agricultural landscape changes

The turning point in radical changes of Czech landscape in the 20th century was the time of collectivization launched in the mid-1950s. In the first stage of land consolidation plots of land were usually designed in such a way so that not to disturb hydraulic amelioration works and erosion control and so that replotting and changes in land use did not disturb the contemporary road network. After 1958 synoptic projects of land consolidation were drawn with the objective to manage the newly organized land resources with the help of enlarging tracts of land and constructing a new road and drainage network. As of 1973 all work on this type of synoptic land consolidation in Czechoslovakia was halted. Focus shifted to the processing of plans concerning the development, concentration and specialization of agricultural production.

Selected methods of monitoring and assessment of the condition and changes of landscape diversity (or biodiversity - eco-stabilization elements and components of landscape) with the help of remote sensing and GIS are illustrated on the case of an agricultural area subject to intensive farming in the vicinity of Horosedly (reference area covering $7.3 \mathrm{sq} \mathrm{km}$ - Písek region, South Bohemia). The detected changes were analyzed in the periods before collectivization and shortly before the comeback of market economy in the last century (Žaloudík, Hanousková, Kolejka 2003).

Methods of landscape ecological research were implemented in the following areas:

- collecting and inventory of basic data and information on the area

- field reconnaissance and mapping

- assessment of landscape diversity (its forms, structure and changes).

The digital image processing was done with the help of EASI/PACE software from PCI Canada, the editing and statistical analysis of GIS data was processed in ArcView produced by ESRI. The data analysis drew on panchromatic aerial photographs from August 29, 1952 and June 14, 1988 (obtained in the form of positive contact photocopies in the scale of $1: 23000$ ) and on a number of thematic maps. The processing itself encompassed a wide range of different methodic procedures of remote sensing and GIS (e.g. digitalization and geometric correction of photographs, image slicing, visual and semi-automated interpretation, multi-temporal synthesis, editing of linear and polygonal layers, post-classification comparison, identification of the area's invariants, multi-criteria analysis and verification of the expert assessment). In the course of the final identification and assessment of the studied landscape changes the method of superposition of developed component thematic masks (vegetation, roads, differentiation of agricultural areas) was implemented to determine the temporary-spatial differences or concord of the studied objects (comparison was done with the help of logical operations with bitmaps - their difference and intersection).

The implemented methodic procedures identified and assessed the following categories of interest objects: plots of agricultural land and the means of their differentiation (plot arrangement), vegetation cover (forests and scattered vegetation), road network (roads, field or forest trails), interaction elements and significant landscape ecosystems (from the perspective of territorial systems of ecological stability). The discovered facts can be summarized in the following categories: 


\section{1. 1 Assessment of changes in land allotment}

The average differentiation ratio of the studied area was approximately 12 times higher in analysed period (the total ratio of plots being 800:65), which means that viewed from this perspective the diversity of contemporary landscape has diminished. The average size of historical plots in the given area was approximately $0.74 \mathrm{ha}$, at present it is approximately $9.14 \mathrm{ha}$. Exception to the rule can be traced only in the urban areas (crofts, gardens and orchards) or in areas of the hardly accessible river Skalice floodplain which in the period of 1952-1988 did not significantly change in terms of size, shape or location (approx. 40 very small sectional plots).

Historical layout and land/plot orientation in landscape respected the terrain and soil conditions of the area (compare the elongation of tillage routes along the contour line), humidity conditions (connection to the

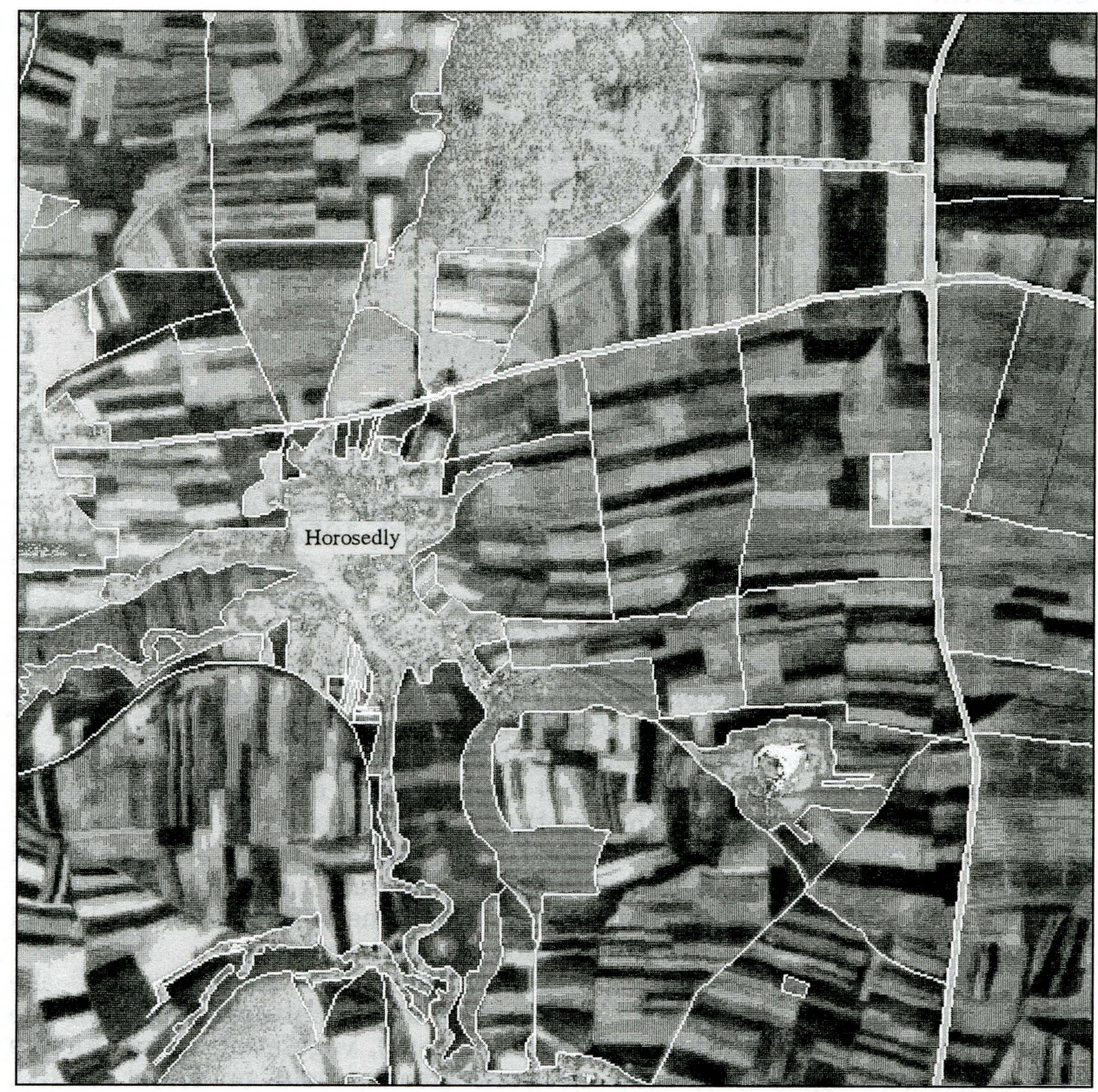

Fig. 4 - Present large-scale allotment of the model area (white lines highlight the boundaries of the main allotment units from 1988) on the background of a historical photograph (with the original layout of agricultural areas in 1952) 
amelioration channels - old irrigation and drainage systems) and socioeconomic conditions of the area (settlement conditions, types of transport and small-scale agricultural production - with the need to bring plots as close as possible to the places of processing and storage).

In contrast, the modern landscape structure of the 1980s and its large-scale allotment virtually lack any sense of adhering to the general principles of practical differentiation of plots from the perspective of land resources protection (erosion, humidity conditions), the conservation of landscape stability (fields and ecosystems), biodiversity development, area's barrier-free accessibility or the diversity of the landscape mosaic (including the perception of the landscape character). Today the measures aimed at rectification of this situation are generally exerted secondarily via supplementary and restoration measures in landscape (Fig. 4).

\section{1. 2 Assessment of vegetation cover changes}

The executed analysis focused mainly on the presence of continuous forests, scattered vegetation both in open landscape (hedgerows, solitary trees, bank vegetation, alleys along roads and others) and in settlements (intravillan wood species vegetation in parks or public gardens).

The analysis of total differences of forests and scattered vegetation in the model area (increase and decrease in the period of 1952-1988) via implementing synoptic and partial masks of the tree-shrub vegetation revealed that the total vegetation area and the occurrence frequency of its functional eco-stabilization forms has significantly increased in the agricultural area.

In 1988 the area of wood species vegetation exceeded the incipient situation in 1952 by 17 per cent (11.4 ha), while in open agricultural landscape the increase was significantly higher (by up to 53 per cent, i.e. $9.4 \mathrm{ha}$ ). This situation can be explained by forest restoration of certain areas not suitable for agricultural use (forestation) or by natural succession development in unused or inaccessible parts of the area (waterlogged areas, forest edges, hedgerows and ditches, deserted quarries) which encompassed even forests (development of unbroken young growth or natural seeding). Plots of land which became marginal in terms of large-scale agricultural production reached a higher stage of structural differentiation and more advanced succession stages of development in many places. They developed both shrub and tree layers, which gives evidence of a long-term biota stabilization in the area.

A slight decrease in tree vegetation can be traced only in the case of local occurrence of settlement greenery (parks and gardens) and due to artificial intervention of people in some forest stands (exploitable forest management, higher ratio of clear felling). A leap (decrease) in tree vegetation are then apparent along road network (as a result of alley felling in the course of widening or construction of roads, as a result of eliminating old roads or others).

From the ecological and landscape perspective it is interesting to assess the condition and development of those landscape ecosystems which enable to conserve biodiversity and the positive development of vegetation structures stabilizing the landscape even in the generally unfavourable conditions of an area subject to intensive farming. The ratio between ecosystems with good auto-regulatory abilities and the less stable vegetation components of 
landscape is $4.5: 1$ (in 1988), respectively $3.55: 1$ (in 1952). The mutual ratio between the present and historical extent of such ecosystem areas is 1.23:1, which constitutes a slightly positive increase.

\section{1. 3 Assessment of changes in the area's accessibility}

The area's accessibility was analyzed in terms of the existing (former or present) network of identifiable spatial lines which can be used for transport or pedestrian traffic in the landscape (roads, railroads, field and forest trails, dried-up amelioration channels or ditches).

In order to compare the level of the area's overall accessibility, the total length and density or these lines and their spatial layout must be taken into account (type and regularity of the network, its prevailing orientation), possibly the existence of important spatial barriers. In 1952 roads create a relatively dense regular network (without basic directional restrictions of accessibility and barriers). In 1952 the length of road network in the area was $59.7 \mathrm{~km}$ (density $8.2 \mathrm{~km} / \mathrm{sq} \mathrm{km})$. In 1988 it was $32.2 \mathrm{~km}(4.4 \mathrm{~km} / \mathrm{sq} \mathrm{km}$ ), which is approximately 46 per cent less in comparison to the initial situation.

A complex assessment and synthesis of data acquired from aerial photograph and map analysis enabled us to analyze the general condition and development of the studied agricultural area's landscape structure (its diversity and stability). It became apparent that exact qualitativequantitative data from remote sensing contribute greatly not only to correct purpose-driven interpretation of landscape structures (the character and layout of their elements and components), but also facilitate a better formulation of optimization proposals for ecological landscape management (when assessing relevant interactions and changes in landscape). Introduction of geo-information methods into the traditional exploration of landscape objects and phenomena, and the use of multi-temporal image data in particular, not only considerably enhance the informative value of a data collection but also conveniently widen the overall information scope, objectivity and realization possibilities of a given landscape changes research.

\section{2 Satellite images - monitoring of changes in protected nature areas}

The main objective of the case study of National Nature Reserve (NNR) Velký and Malý Tisý (Žaloudík, Śíma, Kolejka, 2005) was to detect changes in the structure and condition of pond ecosystems and to outline ways of land use by using the method of digital processing and remote sensing data interpretation. The reference area for localizing the identified landscape changes was the reserve's vicinity, defined as the catchment area of the studied pond system covering $19.1 \mathrm{sq} \mathrm{km}$.

As digital data sources were used satellite records from Landsat 5 - Thematic Mapper from October 26, 1988 and July 10, 1995 (the terrestrial pixel resolution $30 \times 30 \mathrm{~m}$ ). The records came as identical sections of the image scene so that the wider interest area of NNR was covered by qualitatively homogenous satellite information from all the seven spectral channels.

Apart from distinct local changes in the development of the protected pond system (long-term changes in the extent and distribution of the water bodies and littoral areas were discovered on 13 per cent of the reserve's area with the help of aerial photographs from 1949, 1967 and 1995) significant recent 


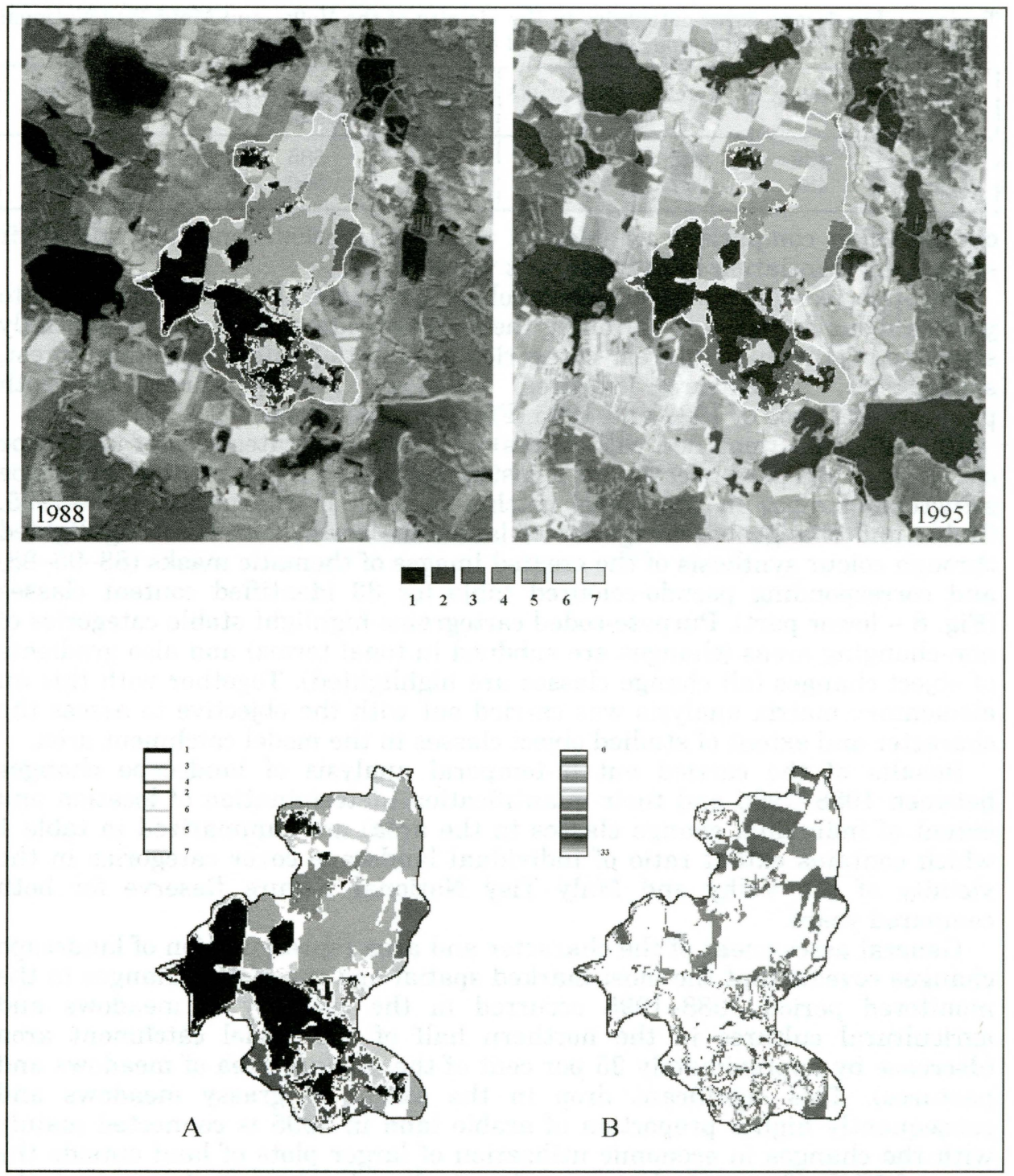

Fig. 5 - Condition and changes of land cover in the protected area and vicinity of the NNR Velký and Malý Tisý on satellite images from 1988 and 1995. Upper part: Differentiation of land cover of the distant surroundings of the National Nature Reserve Velký and Malý Tisý on satellite images from 1988 and 1995, Legend: 1 - water, 2 - wetlands, 3 - forest, 4 - settlements, 5 - fields, 6 - meadows and pastures, 7 - others; lower part: Postclassification assessment of land cover changes between 1988-1995, A - coding of stable object categories, B - coding of the change gradient.

changes affected also the vicinity of the NNR of Velký and Malý Tisý. This can be documented by analysing available satellite images from 1998 and 1995 in all the catchment area of interest (Fig. 5).

The analysis of time changes of the model area's structure (landscape cover and land use) encompassed a two-stage process of detection and post- 
Table 1 - Landscape cover categories in the vicinity of the Velký and Malý Tisý National Nature Reserve for both compared years (all entries are in hectares)

\begin{tabular}{|c|c|c|c|c|c|c|c|}
\hline Year & Water & Forest & Settlements & Wetlands & $\begin{array}{c}\text { Meadows, } \\
\text { pastures }\end{array}$ & Fields & Other \\
\hline 1998 & 439 & 242 & 74 & 49 & 385 & 548 & 173 \\
1995 & 487 & 227 & 74 & 52 & 250 & 692 & 128 \\
\hline
\end{tabular}

classification comparison of selected object categories' condition and their spatial differentiation in the reserve's vicinity.

Through transforming optimized colour syntheses of satellite images into pseudocolour tables and through their thresholding we at first partially separated individual interest categories of objects (water, wetlands, forest, settlements, agricultural cultures, meadows and pastures) for both photograph terms of 1988 and 1995 (Fig. 8 - upper part).

Raster masks (modified with filters) for individual categories of landscape cover were then used to carry out a post-classification assessment of landscape structure changes in the model catchment area in the period 1988-1995. Stable and changeable categories of landscape cover were then highlighted through colour synthesis of the created images of thematic masks (88-95-88) and corresponding pseudo-coloured table for 33 identified content classes (Fig. 8 - lower part). Purpose-coded cartograms highlight stable categories of non-changing areas (changes are subdued in tonal terms) and also gradients of object changes (all change classes are highlighted). Together with this an elementary matrix analysis was carried out with the objective to assess the character and extent of studied object classes in the model catchment area.

Results of the carried out bi-temporal analysis of landscape changes between 1988-1995 and their quantification (determination of location and extent of individual change classes in the area) are summarized in table 1 which contains extent ratio of individual landscape cover categories in the vicinity of the Velký and Malý Tisý National Nature Reserve for both compared years.

General assessment of the character and area representation of landscape changes reveals that the most marked spatial and functional changes in the monitored period 1988-1995 occurred in the category of meadows and agricultural cultures in the northern half of the model catchment area (decrease by approximately 35 per cent of the original area of meadows and pastures). This significant drop in the extent of grassy meadows and consequently higher proportion of arable land in 1995 is connected mainly with the changes in economic utilization of larger plots of land outside the area of NNR (frequent changing of agricultural cultures). Apart from the "settlements" category, also wetland zones remained virtually unchanged (despite their drying-up and overgrowing with shrubs). Small local changes can also be detected in object categories "forest" and "scattered vegetation" (slight decrease in trees in favour of other objects) and also in "water objects" where overall areal increase was detected while the original layout of water planes remained the same (the difference can be accounted for water discharge or higher water level in reservoirs, rather than real changes in hydrographic conditions). The remaining identified changes in the model area do not bear great importance in terms of the overall differentiation of landscape cover nor in relation to the studied pond ecosystems. Moreover, part of the changes is directly related to partial interpretation interferences (e.g. to the problem of transitional mixels on the edges of homogenous areas). 
The applied methods of processing and analyzing digital satellite images facilitated not only the correct location and exact analysis of the most significant changes in the model area of NNR Velký and Malý Tisý in terms of area and importance. The methods also enabled us to quantify, appropriately cartographically represent and archive them in a special database for prospective comparative studies or further use. The demonstrated method of digital image analysis and territorial changes documentation is practically irreplaceable with the traditional terrestrial inventory methods.

It transpired that marked spatial changes of landscape elements and components cannot be avoided even in strictly protected areas. The aforementioned NNR displays both spontaneous evolutionary changes of nature and changes connected directly or indirectly with human activities in landscape (changing intensity and ways of farmland use, nutrients brought in from the catchment area, water pollution, fish management and others). Taking into consideration the significant changes taking place in the vicinity of the NNR, we can presume certain connection between them and the area of the NNR itself.

6. 3 Old and contemporary maps in GIS - Changes of the floodplain landscape in the impact zones of nearby towns and villages

An experimental method was employed for mutual spatial and chronological comparison of the eco-stabilization effect of land use in the floodplain of the Svratka river south of Brno up to the confluence with the Dyje. The total of 39 conventional territorial units in three categories was defined in the floodplain with the objective to statistically localize identified changes. The first category encompasses the "closer surroundings" of a settlement represented by a circle with $500 \mathrm{~m}$ radius. In this space everyday and intensive human activities are expected. Centres of settlements localized on the floodplain's perimeter were taken for the centres of individual circles, resp. bridges across the river in the settlements' immediate surrounding which overcome the river's barrier effect. "Distant surroundings" of a settlement with their commonplace yet not everyday economic utilization make up a circle in the floodplain with $1000 \mathrm{~m}$ radius. The remaining area between the circles was termed "free floodplain" with anticipated lower intensity of utilization owing to its distance from settlements. In places of two main historical fords across the river near Židlochovice and Vranovice the floodplain was divided into three sections.

In the four studied periods of 1824-46 (stable cadastre), 1876-80 (Third Military Mapping), 1953-60 (topographic mapping in the S-JTSK system) and 1992 (aerial surveying) we determined area representation of individual forms of land use in component study sites within the listed categories. Each form of land use was numerically evaluated by the so-called ecological stability level (ESL) based on its eco-stabilization effect. Generally speaking, it is expected that the closer a given form of land use is to the natural form, i.e. forest (reading 7), the deeper its eco-stabilization effect in the environment will be (built-up area has reading 1 ). For each study site in each period a so-called coefficient of ecological stability (CES) was calculated as an integrated manifestation of all the represented forms of land use on its 


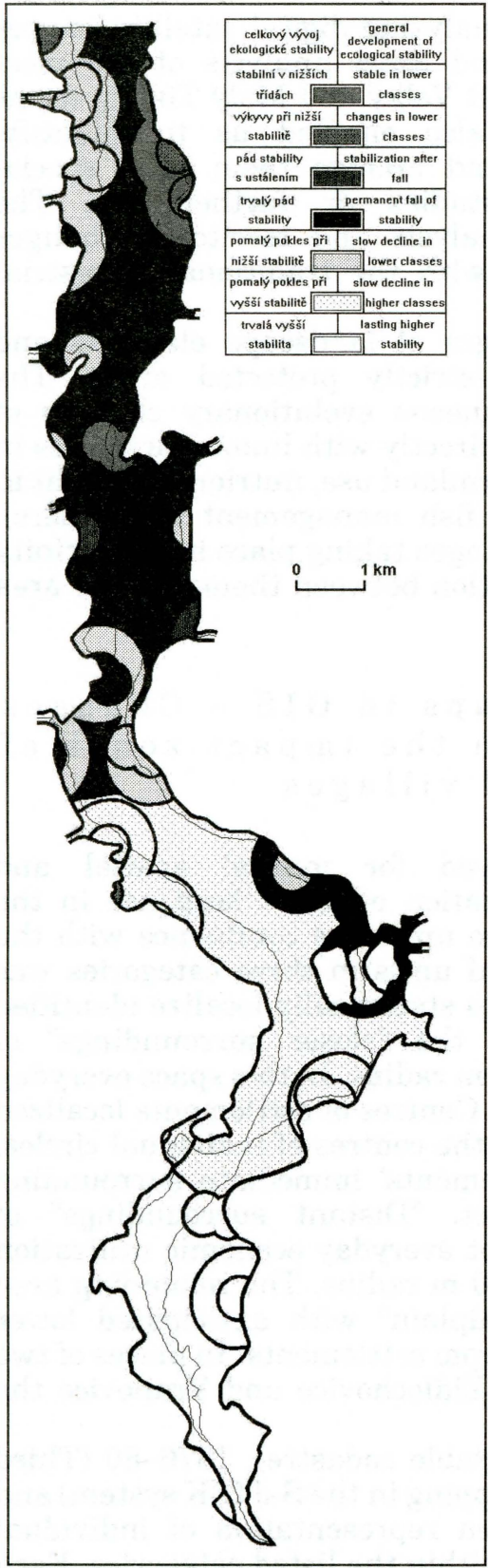

Fig. 6 - Development trends of ecological stability of landscape between the years 1825-1992 in relation to the changes in land use in the Svratka river floodplain near Brno (in closer and distant surroundings of settlements and in free floodplain) ecological stability (ES). This resulted in a survey of the Svratka floodplain's spatial diversification which reflected the growing ES levels south of Brno in every studied period.

The next stage involved calculating the differences in CES values between individual periods in every study site. From the time series of these differences a development ES trend for each site was inferred (Jurnečková, Kolejka 1999). Based on the degree and character of the changing CES levels a number of types of development ES trends were distinguished (Fig. 6). While sites closer to Brno were characterized by their constant gradual ES decline, southern edges of the Svratka floodplain show an opposite trend even though they are situated in the same natural environment. The growing polarity of the floodplain can be attributed to Brno's limited economic impact on the Svratka floodplain. This relatively inconspicuous phenomenon has not so far met any response in terms of remedial measures in the area and remains outside the focus of conservationist activities.

\section{4 Old maps and}

orthophotos in GIS

- Identification of

development trends of land

use in given natural

conditions

The Czech-Bavarian border running through the Sumava mountains is one of the oldest and most stable borders between European states. Yet its vast forests have never presented an insurmountable obstacle and innovation always travelled in both directions. More accurate and detailed data on the real appearance of its cultural landscape date back to the 18th and in particular to the 19th century when landscape survey along either side of the border was carried out. First mutually comparable data come from the first half of the 19th century. Since then a number of quite detailed and reliable cartographic data have been collected on both sides of the 
border. These data document land use in the course of the past two centuries and the landscape's natural conditions.

The comparison focused on the cadastre of Strážný on the Czech side with attached cadastre of the former settlement Silnice (the area's conventional designation being "Strážný"). German side is represented by the settlement Philipsreuth with attached villages of Vorder-, Mittel- and Hinterfirmiansreuth (the area's conventional designation being "Philipsreuth"). Both monitored areas are immediate neighbours on the Czech-German frontier. The basic principle of our choice was their location on the Sumava planes and their similar natural conditions which were at the basis of their human utilizing. The total area of Strážný is $13.1 \mathrm{sq} \mathrm{km}$ and Philipsreuth covers $10.2 \mathrm{sq} \mathrm{km}$. Comprehensive and varied information on both areas of interest was collected and it facilitated the creation of a digital landscape model (a multi-laterally integrated database) of entirely analogous content for both monitored areas. This model included a digital map of natural background (with homogenous typological natural landscape units described by their climatic, geological, humidity, soil and other characteristics) and maps of land use from the first half of the 19th century, the time before WW2 with predominantly German inhabitants settled on either side of the border and from 2002, shortly after the fall of the iron curtain. Homogenous natural landscape units were used as reference sites for geographical localization of identified changes in the landscape. A related sociological localization focusing on a number of aspects of population structure and local economy is in the process of completion.

The identification of development trends of land use draws on the analysis of area representation of individual forms of land use in individual types of natural landscape units. Basic spatial analyses were conducted with the help of ArcView GIS software and its extension Spatial Analyst. The acquired data were statistically processed in Microsoft Excel and classification procedures drew on Excel's programme Unistat 5.5.

The geo-statistic data analysis yielded a great number of comparative tables, graphs and development curves. A glimpse at the histogram of changes in area distribution of forests, meadows, arable land and built-up area in analysed periods based on individual types of natural environment in Strážný and Philipsreuth (Fig. 7, see groups 13 - humid units and 14 -podsolic units which are both abundant on either side of the border) suggests that despite similar natural properties the point of departure in terms of land use in the first half of the 19th century was different for each area, owing to the different economic orientation and different economic specialization of the border settlement population. Twists of fate of pre-war years did not facilitate any approximation of land use in the different national parts, in spite of the fact that there were few ethnic differences in their respective populations (the percentage of Czechs among the inhabitants of Strážný and Silnice was negligible). It transpires that the main reason was a different economic climate on either side of the border. Majority of population on the Czech side found work in forests, which was not sufficient to support families and as a result other (predominantly farming) activities were a bare necessity. On the German side field farming probably played only a minor role and its importance continued to diminish. Following the Munich Treaty both areas on either side of the border were united in a higher administrative unit but the areas remained different in economic terms. This difference was manifested in a different structure of land use which was conditioned by differentiated pressure on land reflecting different standards of living. In 


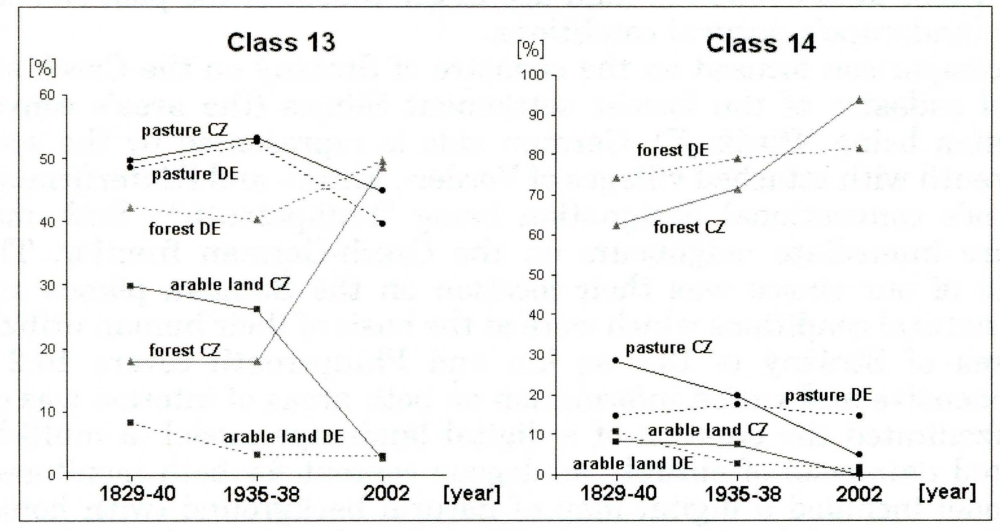

Fig. 7 - An example of convergent land use between 1825 and 2002 in natural landscape units characteristic for both border areas

post-war years it was predominantly the Czech side which saw a radical change of politico-economic situation. After majority of the German population had been resettled a border zone was established which considerably limited the area's economic use and consequently its settlement. The municipality Silnice practically disappeared. Old farmhouses scattered along the border were deserted and only customs office buildings and the border crossing remained from the original village. Even these buildings were used occasionally when needed for the guarding of state border. Similarly, in Strážný a number of farmhouses were deserted. Population decrease and political obstacles resulted in a drop in land pressure, which in turn facilitated gradual natural succession and eventual forests planting on the deserted farmland (both arable land and meadows). The German side experienced a less obvious population reflux into inland and also the decrease in land pressure was less pronounced, among other things owing to a formerly weaker orientation towards farming production. Restructuralization of employment highlighted the recreational function of all the settlements, Mittelfirmiansreuth in particular, which developed into a winter sports resort with relevant facilities and infrastructure. A similar development, in particular after 1989, can be detected in Strážný where a network of tourist and entertainment services has been built, including extensive "stall trade" activities. The area of arable land in the interest area is negligible on both sides of the border today. Apart from the intravilan of Strážný the entire area on the Czech side is protected as a part of the Sumava National Park and the area east of the international road connecting Passau and Vimperk as a part of the Sumava Protected Landscape Area. The German side does not have a similar status of land protection.

Remarkably, the development on one side was distinctly different from and virtually independent of the development in its counterpart across the border. The area has seen a physiognomic (visual) land convergence, particularly in terms of the distribution of forest units, meadows and pastures on either side of the border within the analogical types of natural environment and location. It has also seen the development of a similar structure of land use in a number of natural landscape unit types represented in both national areas. 
Should then large parts of both areas show identical or similar natural conditions, their structure of use concurs as well. On the other hand, specific types of natural environment without a corresponding equivalent abroad tend to have different structures of use. A hypothesis presents itself to explain these facts: along both sides of the border a "generally rational" structure of land use is formed which respects (today and in the recent past) the marginalization of the area, its gradual depopulation, extensification of agriculture, and also strengthens its recreational role regardless the prevalent socio-economic system and standard of living.

ArcView GIS software tools enable us to create applicable statistical background documentation for more detailed analyses and data syntheses. Each type of a natural landscape unit, separately for the Czech and the German parts of the area, was described by an appropriate percentage of the represented forms of land use in all three analyzed periods. Owing to the fact that a decisive share of all the units was always constituted by forests, meadows and possibly by arable land, these dominant physiognomic units (defining the character) of cultural landscape were selected for further assessment. Each group of types of natural landscape units both in the Czech and German parts was described by a nine-digit vector whose co-ordinates represented the percentage of forests, meadows and arable land in the years 1829-1840, 1935-1938 and 2002. These vectors representing every homogenous natural landscape unit in both border areas were classified with the help of cluster analysis implementing the method of "Furthest Neighbour". The resulting outcome represents development trends of land use in different types of natural environment. (Marek 2004).

Five groups of landscape units with similar development were identified: A, B, C, D and E. The fifth one, group E, exists in Germany but does not have analogy on the Czech side. However, its size is negligible and as such was not subject to further analyses. For pairs of natural landscape unit groups subject to similar development representative histograms and maps of land use changes were drawn, as they are indispensable for interpreting the classified development (Fig. 8 - parts a, b).

It became apparent that in order to achieve a similar target effect, i.e. highly similar present use, individual groups of natural landscape units separately in the Czech and German parts "chose" either entirely different or on the contrary identical strategies.

The group of natural landscape units of type A, which includes predominantly areas of valley bottoms and stony hillsides on both sides of the border, is characterized by an antithetic development connected with a dramatic loss of arable land and increase of forest on the Czech side, while on the German side the changes of land use are negligible. Despite this the structures of land use on both sides of the border converge. Group B with similar representation of units which considerably differ in humidity conditions is characterized by a gradual development on the German side and a similar but faster development on the Czech side. However, the structure of land use in these units remains radically different. The German side is predominantly forested, the Czech side shows a balance between forests and meadows. Units of type C include extreme stony (or wet) units and demonstrate an identical development over the entire period of time on both sides of the border, showing a slight fluctuation in the percentage of monitored forms of land use. Dramatic and entirely different changes characterize the group of units D on both sides of the border. However, these 

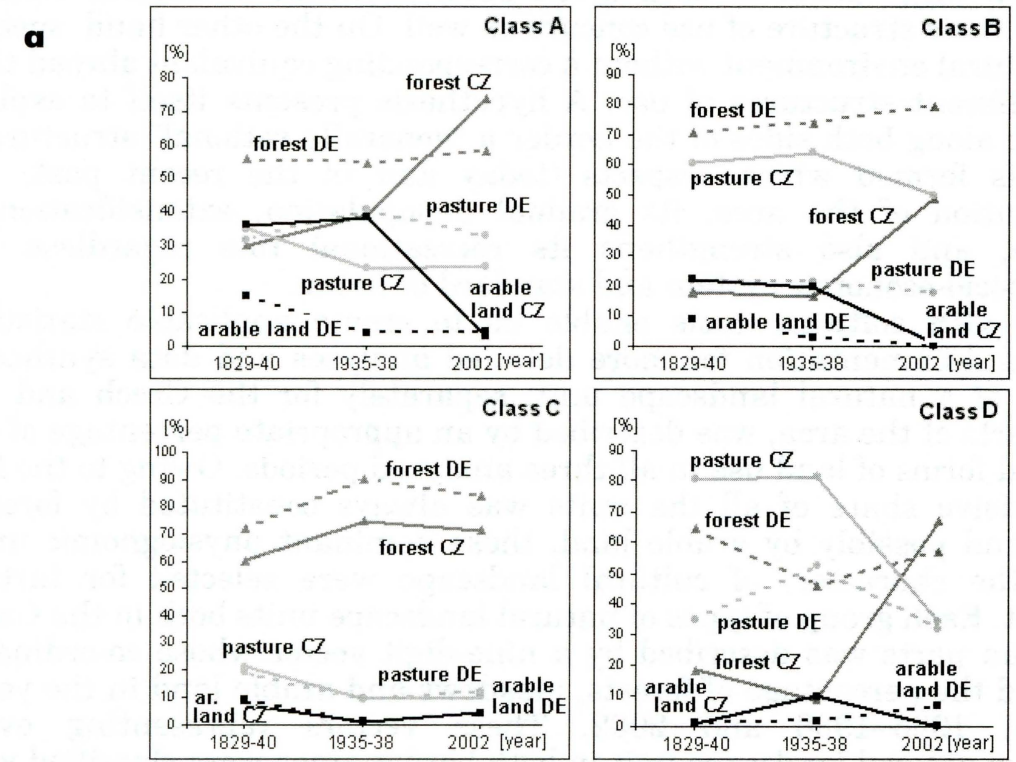

b

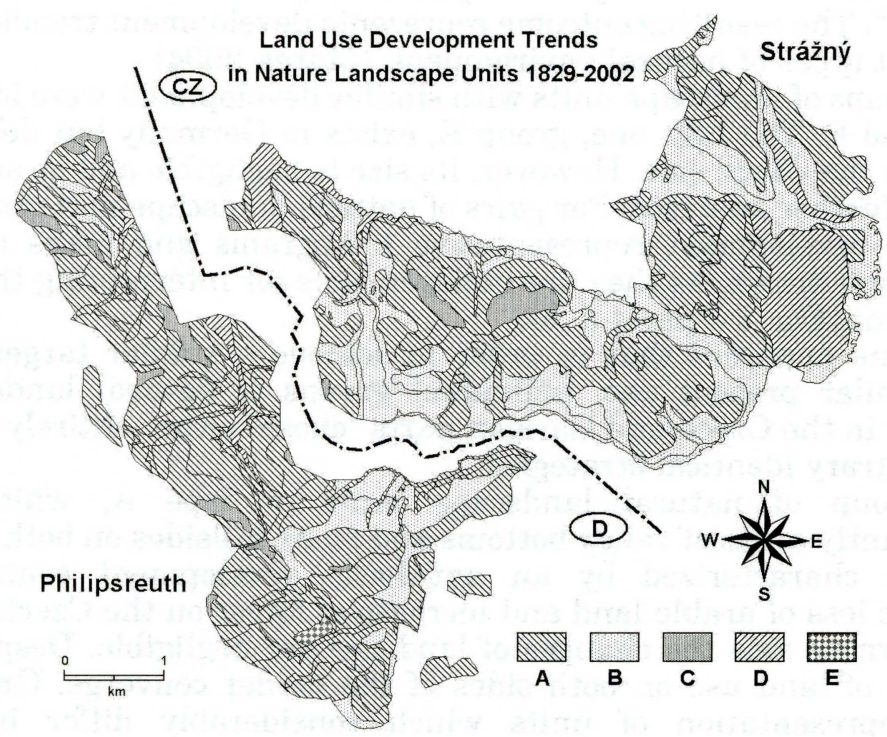

Fig. 8 - Groups of natural landscape units based on the identified development trends of land use (8a) and their projection in the map $(8 b)$

lead to an almost perfect convergence of the present land use with forests slightly prevailing over meadows. Group E exists only on the German side and shows a loss of forests which remain scarce, while dominant meadows gain dominance and arable land is eliminated. 
Generally speaking, both the entire area and its individual types of natural landscape units (except group B) are characterized by land use convergence (Fig. 8a). However, strategies for achieving this convergence differ: from highly chaotic changes in the past (D) to a more extreme concept of trends on the German side (A) or a completely analogical development (C). The data obtained from the interest area prove that the tendency towards a "rational" organization of a functional landscape mosaic is generally consistent regardless the ruling political or economic systems. It also proves that population density and partially people's standard of living, or "economic climate", play a dominant role. Relating to the general trend of European Union to secure the same standard of living for all population communities, the creation of a homogenous economic climate could prove counterproductive to the efforts to maintain a high diversity of cultures and cultural landscapes.

\section{Conclusion}

The objective of this paper is not to provide a comprehensive survey of methods used in Czech geography to identify landscape changes. It can be viewed as an effort to document the principal groups of methods in individual case studies. The study of this phenomenon in Czech geography encompasses a wide range of projects of varying localization specifications - ranging from a simple time line of recorded changes, to statistic localization in the interest area as a whole (cadastre areas or another type of defined space, e.g. a map sheet or its sector), geometric localization in a given place with given topological coordinates, geographic localization in an area with given natural or environmental characteristics to relating the obtained results to the area's given social and economic parameters. The more demanding and complicated the need for a temporary-spatial coincidence of reality, the more important modern geoinformation technologies become, should it be in terms of collecting , processing and analyzing data or in the presentation of one's results. Needless to say that these technologies have substantially helped us progress in the study of landscape changes and that they have facilitated the acquisition of data which are new both quantitatively and qualitatively and which have moved our knowledge substantially forward. Experts studying landscape changes in Czechia closely follow technological development and are already considering employing new, more advanced technologies to detect and localize landscape changes (e.g. laser imaging), this time in 3D geographical space. Furthermore, new geo-information technologies facilitate animations of detected changes and optimize the ways of sharing research results with specialists and general public (Svatoňová 2005). A better understanding of landscape changes, their causes and impact form a suitable basis for optimizing landscape management.

\section{References:}

BIČÍK, I., KUPKOVÁ, L. (2001): Long-term changes in land use in Czechia based on the quality of agricultural land. In: Proceedings of the IGU-LUCC International Conference "Land Use/ Land Cover Changes in the Period of Globalization". Charles University, Prague, pp. 31-43. DORST, J. (1974): Endangered Nature. (Czech edition.) Praha, Orbis, 406 p.

JURNEČKOVÁ, R., KOLEJKA, J. (1999): Historical development of landscape's ecological stability in the floodplain of the Svratka river between Brno and the Nove Mlýny Reservoirs (in Czech). Geografie XI, pp. 111-124. 
MAREK, D. (2004): Optimization of land use in along the border through geoinformation technologies (in Czech). MZLU, Brno, 105 p.

SVATOŇOVÁ, H. (2005): Historical analogue aerial photographs in digital modeling of landscape (in Czech). GeoInfo Yearbook 2005, pp. 62-64.

ŽALOUDÍK, J., HANOUSKOVÁ, I., KOLEJKA, J. (2003): Evaluation of landscape diversity, ecostabilization components and their changes by methods of GIS and remote sensing in agricultural landscape (in Czech). GeoInfo Yearbook 2003, pp. 57-59.

ŽALOUDIK, J., ŠÍMA, M., KOLEJKA, J. (2005): Landscape changes in the National Nature Reserve Velký and Malý Tisý and its Environs (in Czech). Zivotné prostredie, No. 2, pp. 83-87.

\section{Shrnutí}

\section{MONITOROVÁNÍ VÝVOJE ČESKÉ KRAJINY S UŽITÍM GIS A DPZ}

Různé studie věnované využití půdy jsou pro český geografický výzkum krajiny typické. Digitální geoinformační technologie, které se objevily na počátku 80 . let 20 . století, výrazně změnily možnosti dlouhodobého sledování krajiny. Česko disponuje značným množstvím různých kartografických údajů o minulosti území, které sahají až do 18. století. Po digitalizaci těchto analogových údajů mohl úspěšně začít historický výzkum krajiny. Dvacáté století vylepšilo kartografické databáze leteckými snímky (od 30. let 20. století) a satelitními snímky (od 70. let 20. století).

Článek ukazuje různé aplikace GIS a dálkového průzkumu Země ve výzkumu změn krajiny. Využití leteckých snímků při monitorování a analýze změn zemědělské krajiny se týká poměrné krátkého časového úseku od roku 1952 do dneška a je ukázáno na př́ikladě jižních Čech. Metody digitálního zpracování snímků umožnily identifikovat změny zemědělských pozemků, rozmanitosti krajiny a přístupnosti. Satelitní obrázky byly použity pro sledování změn $\mathrm{v}$ chráněných přírodních oblastech $\mathrm{v}$ krajině jihočeských rybníkü. Za použití metod třídění snímkủ a maskovacích operací byly zjištěny a utříděny změny rozlohy vodních ploch a břehové vegetace.

Byla vypracována sada historických map o využití půdy na základě starých map údolí řeky Svratky jižně od Brna ve východní části země. V povodí bylo vymezeno celkem 39 obvyklých územních jednotek ve třech kategoriích (blízké okolí sídla, vzdálené okolí sídla a volná říční niva podle intensity lidské činnosti). Ekologické vyhodnocení tříd využití půdy a statistické metody umožnily stanovit rozvojové trendy ekologické stability ve všech úsecích nivy řeky Svratky. Digitální model krajiny s plně (logicky) integrovanou databází sestávající ze souboru více parametrových vrstev údajů (př́rodní pozadí, lidský vliv a rozvojové limity) s digitálním elevačním modelem byl použit v oblasti česko-německého pohraničí pro stanovení trendů vývoje krajiny v jednotlivých třídách přírodních krajinných jednotek. Byla zjištěna obecná tendence ke konvergenci využití půdy v podobných přírodních podmínkách (ale v odlišných politických a sociálních podmínkách). Takový jev může v budoucnu ohrozit stávající vysokou rozmanitost kulturní krajiny v Evropě, pokud globalizační a evropeizační proces bude pokračovat bez ohledu na krajinné bohatství.

Obr. 1 - Nejstarší podrobná mapa využití půdy v Česku - Müllerova mapa (A), př́íklad georeferenční mapy z druhého vojenského mapování (B), reambulovaná mapa s podrobným vyznačením využití půdy ve 20 . letech 20 . století (C), černobílá ortomapa zpracovaná GIS (D).

Obr. 2 - Vztahy mezi souhrnnými studiemi o využití půdy a jeho změnami, přesností lokalizace změn a vlastnostmi dané změny. Vlevo odshora dolů: umístění LUCC, chronologické, statistické, geometrické, geografické, sociologické, přesnost:minimální - maximální. Vpravo sestupně zleva doprava: čas, zkoumané území, lokalita, okolí, lidské důvody, lokalizační proměnná.

Obr. 3 - Lokalizace jednotlivých studií o vývoji krajiny v Česku. Modelová území: Horosedly, Sumava, Velký a Malý Tisý, údolí řeky Svratky

Obr. 4 - Stávající velkoplošné rozložení parcel modelového území (bílé čáry označují hranice hlavních parcelních jednotek z roku 1988) na pozadí historické fotografie (s původním rozložením zemědělských území v roce 1952).

Obr. 5 - Podmínky a změny povrchu v chráněné oblasti a v blízkosti národní přírodní rezervace Velký a Malý Tisý na satelitních snímcích z let 1988 a 1995. Nahoře: roz- 
lišení povrchu v širším okolí národní přírodní rezervace Velký a Malý Tisý na satelitních snímcích z let 1988 a 1995. Legenda: 1 - voda, 2 - mokřiny, 3 - les, 4 - sídla, 5 - pole, 6 - louky a pastviny, 7 - ostatní; dole - poklasifikační vyhodnocení změn povrchu mezi lety 1988 a 1995, A - kód kategorií stabilních objektů, $\mathrm{B}$ - kód gradientu změny.

Obr. 6 - Vývojové trendy ekologické stability krajiny mezi lety 1825 a 1992 ve vztahu ke změnám ve využití půdy v povodí Svratky u Brna (v blízkém a vzdálenějším sousedství sídel a ve volné nivě).

Obr. 7 - Příklad konvergentního využití půdy mezi lety 1825 a 2002 v přírodních krajinných jednotkách charakteristických pro obě pohraniční oblasti. Vlevo odshora dolů: trrída 13 , pastviny $\mathrm{CZ}$, pastviny $\mathrm{DE}$, lesy $\mathrm{DE}$, orná půda $\mathrm{CZ}$, lesy $\mathrm{CZ}$, orná půda DE, rok. Vpravo odshora dolů: třída 14, lesy DE, lesy CZ, pastviny CZ, pastviny $\mathrm{DE}$, orná půda $\mathrm{CZ}$, orná půda $\mathrm{DE}$, rok.

Obr. 8 - Skupiny př́rodních krajinných jednotek na základě zjištěných rozvojových trendů využití půdy (a) a jejich projekce $v$ mapě $(b$ - rozvojové trendy využití půdy $v$ př́irodních krajinných jednotkách 1829-2002)

(J. Kolejka is with Masaryk University in Brno, Faculty of Education, Department of Geography, Pořičí 7, 70300 Brno, Czechia, e-mail ; J. Zaloudík is with Institute of Systems Biology and Ecology, Academy of Sciences of the Czech Republic,

České Budějovice, Czechia.)

Arrived to the editorial board on November 4, 2005 